\title{
Prinsip Liberalisasi Perdagangan World Trade Organization (WTO) dalam Pembaharuan Hukum Investasi di Indonesia (Undang-Undang Nomor 25 Tahun 2007)
}

\author{
Acep Rohendi ${ }^{23}$
}

\begin{abstract}
Abstrak
Undang-Undang Nomor 25 Tahun 2007 tentang Penanaman Modal (UUPM) merupakan peraturan mengenai investasi di Indonesia yang menggantikan Undang-Undang Nomor 1 Tahun 1967 tentang Investasi Asing dan Undang-Undang Nomor 5 Tahun 1968 tentang Investasi Domestik. Undang-undang ini tidak lagi membedakan antara investasi asing dan domestik. Pembentukan undang-undang ini merupakan komitmen Indonesia atas diratifikasinya Agreement Establishing the World Trade Organization (WTO Agreement) Pasal $\mathrm{XVI}$, Ayat 4 dari Agreement tersebut mewajibkan negara anggota untuk menyesuaikan aturanaturan atau hukum perdagangan mereka dengan aturan-aturan yang terdapat dalam Annex di WTO Agreement. Prinsip-prinsip WTO yang telah diimplementasikan pada UUPM, yaitu: 1) Prinsip (Most-Favoured-Nation) dalam Pasal 1 ayat (1), Pasal 3 ayat (1), Pasal 4 ayat (2), dan Pasal 6 ayat (1); 2) Prinsip National Treatment dalam Pasal 6 ayat (1); 3) Prinsip Larangan Restriksi (pembatasan) Kuantitatif dapat ditemukan dalam Pasal 8; 4) Prinsip Perlindungan melalui Tarif yang ditemukan secara tersirat pada asas efisiensi berkeadilan dalam Pasal 3 ayat (1) dan Pasal 14; 5) Prinsip Resiprositas dapat ditemukan dalam Pasal 7 dan Pasal 32; 6) Prinsip Perlakuan Khusus bagi Negara Berkembang diatur dalam Pasal 13. Indonesia telah mengimplementasi prinsip-prinsip tersebut sebagaimana diwajibkan bagi negara-negara anggota WTO.
\end{abstract}

Kata Kunci: prinsip liberalisasi perdagangan, World Trade Organization, investasi asing, investasi domestik, undang-undang penanaman modal.

\section{Principle of Trade Liberalization of World Trade Organization (WTO) in Reforming the Investment Law of Indonesia (Indonesian Law No. 25 of 2007)}

\begin{abstract}
Law Number 25 Year 2007 is the investment law of Indonesia which replaces Law Number 1 year 1967 on Foreign Investment and Law Number 5 year 1968 on Domestic Investment. This new law no longer distinguishes foreign and domestic investment. The formation of law Number 25 Year 2007 is the commitment of Indonesia upon ratification of the (WTO Agreement). Article XVI paragraph 4 of the Agreement Establishing the WTO requires state parties to adjust their rules or which law of trade with the rules contained in the WTO
\end{abstract}

23 Dosen pada Program Pascasarjana Universitas BSI Bandung, Jl. Sekolah Internasional Nomor 1-6 Bandung, Indonesia, acep.aph@bsi.ac.id, S.H. (Universitas Padjadjaran), M.H. (Universitas ARS Internasional dan Universitas Padjadjaran). 
Acep Rohendi: Prinsip Liberalisasi Perdagangan World Trade Organization (WTO) dalam Pembaharuan Hukum Investasi di Indonesia (Undang-Undang Nomor 25 Tahun 2007)

Agreement Annex. WTO principles which have been implemented in the Investment Law of 2007 are: 1) Principle of Most-Favored Nation clause in Article 1 paragraph (1), and Article 3 Paragraph (1), Article 4 paragraph (2) and Article 6 paragraph (1); 2) Principle of National Treatment in Article 6 paragraph (1); 3) Principle of Quantitative Restrictions in Article 8; 4) Principle of Protection through tariff found implicitly in Principle of Efficiency Fair in Article 3 paragraph (1) and Article 14; 5) Principle of Reciprocity found in Article 7 and Article 32; 6) Principle of Special Treatment for Developing Countries, provided in Article 13. Indonesia has been implementing these principles as required by WTO.

Keywords: principle of trade liberalization, World Trade Organization, foreign investment, domestic investment, investment law.

\section{A. Pendahuluan}

Perekonomian perdagangan dan investasi tidak hanya saling melengkapi, tetapi juga semakin tak terpisahkan sebagai dua sisi dalam proses globalisasi. Menurut WTO (Direction General), investasi asing secara langsung (foreign direct investment/FDI) bersama-sama dengan perdagangan internasional telah menjadi motor utama proses globalisasi. ${ }^{1}$ FDI menjadi salah satu pendorong terjadinya proses globalisasi ekonomi nasional menjadi ekonomi internasional, bersama-sama dengan faktor lain seperti: perdagangan, aliran dana, migrasi, serta penyebaran teknologi. ${ }^{2}$ Proses globalisasi ini tidak berhenti pada tingkat ekonomi internasional saja, akan tetapi juga menuju pada penyatuan ekonomi secara global dengan globalisasi ekonomi sebagai mega market place. $^{3}$

Investasi merupakan sumber penggerak pertumbuhan ekonomi menuju pembangunan berkelanjutan dalam era global. Investasi suatu negara dapat bersumber dari dalam negeri maupun luar negeri (investasi asing). ${ }^{4}$ Investasi asing merupakan aliran aset dari suatu negara ke negara lain dengan tujuan mendapatkan keuntungan, dengan pengawasan dari pemilik dana. Aliran aset tersebut dapat berupa properti fisik yang merupakan investasi langsung dan aliran aset untuk membeli saham perusahaan di negara lain yang merupakan bentuk investasi portofolio. ${ }^{5}$

1 Re nato Ruggiero, “W T O N e w s: 1996 Press Re I e a s e s", http://www.wto.org/english/news_e/pres96_e/pr042_e.htm, diunduh 20 Mei 2014.

2 Peter N. Stearns, Globalization in World History, USA: Routledge, 2010, hlm. 1.

3 Peter Larose, "The Impact of Global Financial Integration on Mauritius and Seychelles", Bank of Valletta Review, Nomor 28, Autumn 2003, hlm. 33.

4 Lyuba Zarsky, "Introduction: Balancing Rights and Rewards in Investment Rules”, dalam buku International Investment for Sustainable Development: Balancing Rights and Rewards yang disusun oleh Lyuba Zarsky (eds.), London: Earthscan, 2005, hlm. 1.

5 M. Sornarajah, The International Law on Foreign Investment, New York: Cambridge University Press, 2010, hlm. 8. 
Acep Rohendi: Prinsip Liberalisasi Perdagangan World Trade Organization (WTO) dalam Pembaharuan Hukum Investasi di Indonesia (Undang-Undang Nomor 25 Tahun 2007)

FDI telah lama menjadi topik hangat para pengambil kebijakan di negara-negara berkembang. Kontribusi FDI kepada suatu negara adalah sebagai sumber pendanaan dari luar negeri serta pendorong pertumbuhan ekonomi negara tersebut. Perilaku perusahaan multinasional dan regulasi FDI dalam suatu negara merupakan beberapa isu yang harus disikapi oleh para pembuat kebijakan di negara tersebut. ${ }^{6}$

Kemudahan bagi pelaku ekonomi asing untuk menanamkan modal ke dalam suatu negara menjadi suatu isu yang erat kaitannya dengan kedaulatan. Kedaulatan suatu negara semakin berkurang seiring dengan regulasi kebebasan transaksi ekonomi yang meniadakan hambatan-hambatan dan menimbulkan liberalisasi di bidang ekonomi. Integrasi ekonomi nasional ke satu sistem global dalam proses ekonomi seperti deregulasi dan perdagangan bebas bahkan dapat mengancam kedaulatan nasional. ${ }^{7}$

UUPM lahir pada saat masih berlangsungnya perdebatan mengenai pentingnya pengaturan yang lebih tegas terhadap penyelenggaraan investasi di Indonesia yang sudah berjalan selama 40 tahun (1967-2007). Namun pada kenyataannya, masih timbul pertentangan mengenai pembaharuan undang-undang investasi karena pembaharuan tersebut dianggap akan memeras ekonomi bangsa dengan cara menguasai serta mengambil sumber-sumber kekayaan alam. ${ }^{8}$ Alasan penggantian Undang-Undang Nomor 1 Tahun 1967 tentang Penanaman Modal Asing (UUPMA) dan Undang-Undang Nomor 5 Tahun 1968 tentang Penanaman Modal Dalam Negeri (UUPMDN) dengan UUPM, dikaitkan dengan Indonesia sebagai anggota WTO, adalah tidak ada lagi diskriminasi antara modal domestik dengan modal asing sejak diratifikasinya WTO Agreement dengan Undang-Undang Nomor 7 Tahun 1994 tentang Pengesahan WTO. ${ }^{9}$

Pembangunan ekonomi sangat memerlukan sarana dan pranata hukum agar pembangunan ekonomi nasional benar-benar dapat mencapai tujuannya sesuai rencana. "Jalan-jalan pintas yang telah diambil dengan mengesampingkan hukum itu dalam jangka panjang, telah menjerat kita dalam sarang laba-laba yang kita buat sendiri." ${ }^{10}$ Pada saat ini 'nasi telah menjadi bubur', regulasi penanaman modal di

6 José De Gregorio, "The Role of Foreign Direct Investment and Natural Resources in Economic Development", dalam buku Multinationals and Foreign Investment in Economic Development yang disusun oleh Edward M. Graham (eds), USA: Palgrave Macmillan, 2005, hlm. 179.

7 Milivoje Panic, Globalization and National Economic Welfare, New York: Palgrave Macmillan, 2003, hlm. 7.

8 Sujud Margono, Hukum Investasi Asing, Jakarta : CV. Novindo Pustaka Mandiri, 2008, hlm. 1.

9 Erman Rajagukguk, "The New Indonesian Investment Law", Paper Presented in Honor of Professor Emeritus Daniel S. Lev, "Current Issues in Indonesian Law", William H. Gates Hall, University of Washington School of Law in Collaboration with University of Indonesia, Faculty of Law, Seattle, February 27-28, 2007, http://www.ermanhukum.com/Makalah\%20ER\%20pdf/THE\%20NEW\%20INDONESIAN\%20INVESTMENT\%20L AW.pdf, Diunduh 1 Juni 2014.

10 Sunaryati Hartono, Politik Hukum Menuju Satu Sistem Hukum Nasional, Bandung: Alumni, 1991, hlm. 30. 
Acep Rohendi: Prinsip Liberalisasi Perdagangan World Trade Organization (WTO) dalam Pembaharuan Hukum Investasi di Indonesia (Undang-Undang Nomor 25 Tahun 2007)

Indonesia telah diperbaharui oleh UUPM sebagai ketaatan terhadap ratifikasi WTO Agreement. Berkaitan latar belakang ini, bagaimanakah implementasi prinsip-prinsip liberalisasi investasi WTO Agreement dalam UUPM? Tujuan penulisan ini untuk mengetahui prinsip-prinsip umum WTO yang diimplementasikan dalam UUPM.

\section{B. Prinsip-prinsip Liberalisasi Perdagangan WTO dalam UUPM \\ 1. Pembaharuan Regulasi-regulasi Penanaman Modal dalam UUPM \\ a. Latar Belakang Pembaharuan Regulasi Penanaman Modal}

World Bank, selama krisis global 2009, mencatat bahwa perusahaan multinasional dan investasi asing mampu menciptakan jutaan kesempatan kerja, transfer teknologi, peningkatan keterampilan, peningkatan persaingan, kontribusi pajak, teknologi produksi baru, peningkatan transfer pengetahuan ke pekerja lokal, dan pengenalan manajemen baru. Sebaliknya isu-isu perlindungan produk lokal, isu-isu lingkungan dan pencemaran merupakan isu-isu kritis terhadap investasi asing. ${ }^{11}$

Dengan masuknya Indonesia menjadi anggota WTO, kini Indonesia tidak mempunyai pilihan kebijakan (policy option) dalam bidang ekonomi. Kebijakan hanya ada satu yaitu liberalisasi ekonomi ke arah pasar bebas menurut resep yang diberikan WTO. Hal ini mengingatkan kebenaran slogan mantan Perdana Menteri Inggris, Margaret Thatcher, "There is no alternative (TINA)". 12

Terdapat tiga latar belakang lahirnya UUPM. Pertama, faktor ekonomi, yaitu adanya suatu kebutuhan akan sumber dana luar negeri untuk menanggulangi krisis ekonomi dan sumber dana pembangunan ekonomi Indonesia. Kedua, faktor politik sebagai bentuk penaatan dan komitmen terhadap WTO Agreement. Ketiga, faktor hukum, yang menganggap hukum penanaman modal yang berlaku kurang menarik minat investor asing.

\section{b. Kriteria Modal Asing dan Modal Dalam Negeri}

UUPM mendefinisikan modal sebagai aset dalam bentuk uang atau bentuk lain yang bukan uang yang dimiliki oleh penanam modal yang mempunyai nilai ekonomis (Pasal 1 UUPM). Donald Rutherford mengartikan aset sebagai sumber daya yang bernilai pasar atau sebagai unit kekayaan yang mampu mendapatkan pendapatan. ${ }^{13}$

Investment dalam bahasa Inggris diterjemahkan sebagai investasi atau penanaman modal. Hukum positif Indonesia menggunakan istilah penanaman

11 World Bank Group, Investing Across Borders 2010: Indicators of Foreign Direct Investment Regulation in 87 Economies, Washington D.C: The World Bank Group, 2010, hlm. 2.

12 Petrus C.K.L Bello, Ideologi Hukum: Refleksi Filsafat atas Ideologi di Balik Hukum, Bogor: Insan Merdeka, 2013, hlm. 7.

13 Donald Rutherford, Routledge Dictionary of Economics, New York: Routledge, 2005, hlm. 17. 
Acep Rohendi: Prinsip Liberalisasi Perdagangan World Trade Organization (WTO) dalam Pembaharuan Hukum Investasi di Indonesia (Undang-Undang Nomor 25 Tahun 2007)

modal, seperti terlihat dalam UUPM. Secara ekonomi, kegiatan penanaman modal adalah suatu kegiatan menanamkan modal dalam suatu proyek atau usaha untuk mendapatkan keuntungan. Modal merupakan salah faktor produksi selain faktor alam, tenaga, dan kewirausahaan. Pada Pasal 1 UUPM penanaman modal diartikan sebagai segala bentuk kegiatan menanam modal, baik oleh penanam modal dalam negeri maupun penanam modal asing untuk melakukan usaha di wilayah negara Republik Indonesia.

UUPM membedakan kriteria modal asing dan modal dalam negeri berdasarkan kepemilikan modal. Modal asing merupakan modal yang dimiliki oleh investor asing, sedangkan modal dalam negeri merupakan modal yang dimiliki oleh investor domestik dan pemerintah (Pasal 7 dan Pasal 8 UUPM). UUPMA dan UUPMDN menggunakan kriteria sumber devisa untuk membedakan modal asing dan modal dalam negeri. Modal yang bersumber dari devisa luar negeri merupakan modal asing, sedangkan modal yang berasal dari dalam negeri merupakan modal dalam negeri. ${ }^{14}$

Penggunaan kriteria kepemilikan untuk membedakan modal asing dan modal dalam negeri merupakan kriteria yang lebih baik jika dibandingkan dengan kriteria asal devisa. Jadi, meskipun sumber devisa berasal dari dalam negeri tetapi kepemilikannya dipegang investor asing maka modal tersebut dikategorikan sebagai modal asing. Sebaliknya apabila devisa tersebut berasal dari devisa luar negeri tetapi kepemilikannya dipegang oleh investor domestik maka modal tersebut dikategorikan sebagai modal dalam negeri.

Modal asing sebelumnya diatur dalam UUPMA, sedangkan modal dalam negeri diatur dalam UUPMDN. Setelah ada pembaharuan UUPM tentang modal, tidak ada lagi pembedaan antara modal asing dan modal dalam negeri. Hal ini mengandung konsekuensi perlakuan yang sama antara penanam modal asing (investor asing) dan penanam modal dalam negeri (investor domestik). Pelaku ekonomi di Indonesia sebagai investor domestik meliputi Badan Usaha Milik Negara/Daerah (BUMN/BUMD), swasta (perorangan/perusahaan), dan koperasi. Kelompok usaha swasta dapat meliputi usaha besar, usaha menengah, usaha kecil, dan usaha mikro. ${ }^{15}$

\section{c. Asas dan Tujuan Penanam Modal}

Pengertian asas dalam Black's Law Dictionary sebagai principle berarti a basic rule, law or doctrine. ${ }^{16}$ Sebagai aturan dasar dari undang-undang atau doktrin, Sudikno Mertokusumo berpendapat bahwa asas hukum sebagai "dasar-dasar petunjuk arah

Lihat Pasal 2 UUPMA dan Pasal 1 UUPMDN; Bandingkan dengan pendapat Jonker Sihombing, Hukum Penanaman Modal Indonesia, Bandung: Alumni, 2009, hlm. 69.

15 Lihat Pasal 1 angka (1) - Angka (4) Undang-Undang Nomor 20 Tahun 2008 tentang Usaha Mikro, Kecil, dan Menengah.

16 Bryan A. Gadner, Black's Law Dictionary, USA: Thomson, 2004, hIm. 1231. 
Acep Rohendi: Prinsip Liberalisasi Perdagangan World Trade Organization (WTO) dalam Pembaharuan Hukum Investasi di Indonesia (Undang-Undang Nomor 25 Tahun 2007)

dalam pembentukan hukum positif". Asas hukum merupakan latar belakang peraturan yang konkret dan bersifat umum atau abstrak. Asas hukum sesuai cita-cita yang hendak diraihnya. ${ }^{17}$

Pemerintah menetapkan kebijakan dasar penanaman modal untuk: ${ }^{18}$

1. Mendorong terciptanya iklim usaha nasional yang kondusif bagi penanaman modal untuk penguatan daya saing perekonomian nasional; dan

2. Mempercepat peningkatan penanaman modal.

Kedua kebijakan tersebut merupakan dasar untuk memperbaharui undangundang penanaman modal dengan UUPM yang intinya adalah untuk menarik investor asing untuk menanamkan modalnya di Indonesia.

Kesepuluh asas penanaman modal dalam UUPM seperti diatur dalam Pasal 3 ayat (1) UUPM, meliputi: kepastian hukum, keterbukaan, akuntabilitas, perlakuan yang sama dan tidak membedakan asal negara, kebersamaan, efisiensi berkeadilan, berkelanjutan, berwawasan lingkungan, kemandirian, dan keseimbangan kemajuan, dan kesatuan ekonomi nasional. ${ }^{19} \mathrm{Hal}$ ini berbeda dengan ketentuan sebelumnya, yaitu UUPMA dan UUPMDN, yang tidak mencantumkan asas penanaman modal dalam pasal-pasalnya. Keberadaan asas-asas penanaman modal dalam UUPM merupakan kemajuan dari undang-undang sebelumnya (UUPMA dan UUPMDN).

Dikaitkan dengan inti kebijakan dasar penanaman modal, maka asas utama penanaman modal dalam UUPM adalah asas kepastian hukum (asas ke-1 UUPM). Pada Penjelasan Pasal 3 ayat (1) huruf a, yang dimaksud dengan asas kepastian hukum adalah asas dalam negara hukum yang meletakkan hukum dan ketentuan peraturan perundang-undangan sebagai dasar dalam setiap kebijakan dan tindakan dalam bidang penanaman modal. Asas kepastian hukum merupakan asas utama seperti pendapat Didik J. Rachbini, karena posisinya sebagai dasar aturan main bagi kegiatan investasi dan kegiatan ekonomi lainnya yang substansinya ada dalam UUPM.

Asas kepastian hukum tersebut dijabarkan dalam dua kelompok asas. Kelompok asas pertama adalah perlakuan yang sama dan tidak membedakan asal negara (asas ke 4 UUPM). Asas ini meliputi asas: keterbukaan, akuntabilitas, kebersamaan, dan efisiensi berkeadilan. Kelompok asas yang kedua adalah berkelanjutan, yang meliputi asas berwawasan lingkungan, kemandirian, keseimbangan kemajuan, dan kesatuan ekonomi nasional. Kelompok asas ini sebagai standar acuan pasal-pasal dalam UUPM. $^{20}$

17 Sudikno Mertokusumo, Mengenal Hukum, Yogyakarta: Liberty, 1995, hlm. 35.

18 Pasal Pasal 4 ayat (1) UUPM.

19 Pasal 3 ayat (1) UUPM.

20 Didik J. Rachbini, Arsitektur Hukum Investasi Indonesia (Analisis Ekonomi Politik), Jakarta: PT Indeks, 2008, hlm. 23. 
Acep Rohendi: Prinsip Liberalisasi Perdagangan World Trade Organization (WTO) dalam Pembaharuan Hukum Investasi di Indonesia (Undang-Undang Nomor 25 Tahun 2007)

Asas kepastian hukum pada akhirnya harus mencerminkan UUD 1945 sebagai landasan struktur formal hukum positif dan dijiwai oleh falsafah negara Pancasila sebagai cita hukum negara Indonesia. Pancasila merupakan cita hukum Indonesia. Sistem hukum Indonesia antara lain meliputi struktur formal hukum positif di Indonesia (kaidah-kaidah dan asas-asas) yang berlaku berlandaskan UUD 1945. Susunan yang demikian menempatkan Pancasila sebagai cita hukum negara Republik Indonesia dan dinamakan cita hukum Pancasila. ${ }^{21}$

Pasal 3 ayat (2) UUPM disebutkan bahwa tujuan penyelenggaraan penanaman modal antara lain: (1) meningkatkan pertumbuhan ekonomi nasional; (2) menciptakan lapangan kerja; (3) meningkatkan pembangunan ekonomi berkelanjutan; (4) meningkatkan kemampuan daya saing dunia usaha nasional; (5) meningkatkan kapasitas dan kemampuan teknologi nasional; (6) mendorong pengembangan ekonomi kerakyatan; (7) mengolah ekonomi potensial menjadi kekuatan ekonomi riil dengan menggunakan dana yang berasal baik dari dalam negeri maupun luar negeri; dan (8) meningkatkan kesejahteraan masyarakat.

Didik J. Rachbini mengungkapkan peranan dan fungsi investasi dalam sistem perekonomian. Investasi merupakan salah satu sarana yang sangat menentukan perkembangan perekonomian Indonesia. Faktor investasi bersamaan dengan faktor pengeluaran pemerintah dan faktor ekspor merupakan faktor injeksi yang memperkuat sistem perekonomian. Kegiatan investasi berhubungan langsung dengan sistem produksi, kegiatan perdagangan dan ekspor, serta kegiatan masyarakat pada umumnya. Dampak ganda investasi sebelum berpengaruh terhadap pertumbuhan ekonomi, berpengaruh juga terhadap kegiatan ekonomi lainnya. Inilah keterkaitan investasi dengan kegiatan ekonomi dan kesejahteraan masyarakat. ${ }^{22}$

Tujuan penyelenggaraan penanaman modal dalam UUPM dapat dianalisis melalui pendekatan dari sisi proses, output (keluaran) dan outcome (hasil). Tujuan UUPM dari segi proses adalah mengolah ekonomi potensial menjadi kekuatan ekonomi riil dengan menggunakan dana yang berasal baik dari dalam negeri maupun dari luar negeri, ${ }^{23}$ tujuan dari segi output (keluaran) meliputi peningkatan pertumbuhan ekonomi nasional, dan tujuan dari segi outcome adalah meningkatkan kesejahteraan masyarakat.

21 Mochtar Kusumaatmadja dan B. Arief Sidharta, Pengantar Ilmu Hukum: Suatu Pengenalan Pertama Ruang Lingkup Berlakunya Ilmu Hukum, Bandung: Alumni,2000, hlm. 121-122.

22 Uraian Rumus: $\mathrm{Y}=\mathrm{C}+\mathrm{I}+\mathrm{G}+(\mathrm{X}-\mathrm{I}), \mathrm{Y}=$ Pendapatan Nasional, $\mathrm{C}=$ Konsumsi Nasional, I=Investasi, G=Pengeluaran Pemerintah, X=Ekspor, I=Impor, DidikJ. Rachbini, Arsitektur Hukum Investasi...., Op.cit., hlm. 13-14.

23 Pengertian pembangunan ekonomi, lihat Konsiderans menimbang huruf c UUPMA. 
Acep Rohendi: Prinsip Liberalisasi Perdagangan World Trade Organization (WTO) dalam Pembaharuan Hukum Investasi di Indonesia (Undang-Undang Nomor 25 Tahun 2007)

Tujuan dari segi output (keluaran) meliputi peningkatan pertumbuhan ekonomi nasional ini mencakup tujuan untuk menciptakan lapangan kerja, meningkatkan kemampuan daya saing dunia usaha nasional, meningkatkan kapasitas dan kemampuan teknologi nasional, mendorong pengembangan ekonomi kerakyatan, dan meningkatkan pembangunan ekonomi berkelanjutan.

\section{d. Bidang Usaha Penanaman Modal}

Pasal 6 dan Pasal 7 Bab III UUPMA mengatur bidang usaha PMA yang meliputi bidang usaha dengan skala prioritas, bidang usaha tertutup, serta bidang usaha yang terkait dengan pertahanan negara. Bidang usaha yang tertutup untuk modal asing ialah bidang-bidang usaha yang tertutup untuk penanaman modal asing secara pengusahaan penuh, yakni bidang-bidang yang penting bagi negara dan menguasai hajat hidup rakyat banyak yaitu: pelabuhan-pelabuhan, produksi, transmisi dan distribusi tenaga listrik untuk umum, telekomunikasi, pelayaran, penerbangan, air minum, kereta api umum, pembangkitan tenaga atom, dan media massa. Pemerintah pun diberi kewenangan oleh UUPMA untuk menentukan bidang-bidang usaha yang tertutup bagi modal asing. ${ }^{24}$

Di sisi lain, bidang usaha penanaman modal dalam negeri, yang diatur dalam Pasal 4 UUPMDN, memberikan keleluasaan bagi investor domestik dengan ketentuan semua bidang usaha dapat terbuka bagi swasta dan bidang usaha negara yang meliputi beberapa bidang yang perusahaannya wajib dilaksanakan oleh pemerintah. Keluasan bidang usaha modal dalam negeri dalam UUPMDN tidak ditemukan dalam bidang usaha modal asing dalam UUPMA. Investor domestik dapat menjalankan usaha pada bidang usaha yang sebenarnya tertutup untuk investor asing.

Pembaharuan ketentuan bidang usaha penanam modal diatur dalam Pasal 12 UUPM yang esensinya hampir sama dengan bidang usaha yang diatur dalam Pasal 4 UUPMDN. Ketentuan baru tentang bidang usaha dalam UUPM adalah terbuka untuk investor asing dan domestik, kecuali bidang atau jenis usaha yang dinyatakan tertutup dan terbuka dengan persyaratan. Bidang usaha yang tertutup bagi investor asing adalah produksi senjata, mesiu, alat peledak, dan peralatan perang serta bidang usaha yang secara eksplisit dinyatakan tertutup berdasarkan undang-undang.

Konsekuensi keterbukaan bidang usaha bagi penanam modal asing dan penanaman modal dalam negeri adalah tendensi timbulnya persaingan usaha yang pada ujungnya pihak bermodal kuat akan memenangkan persaingan usaha ini yaitu investor asing, terutama dalam bidang usaha yang digerakkan oleh usaha besar dan berskala nasional. Tidak tertutup kemungkinan, dalam jangka panjang, perusahaanperusahaan besar berskala nasional atau internasional di Indonesia akan berada di

24 Pasal 6 ayat (1) dan Pasal 7 UUPMA. 
Acep Rohendi: Prinsip Liberalisasi Perdagangan World Trade Organization (WTO) dalam Pembaharuan Hukum Investasi di Indonesia (Undang-Undang Nomor 25 Tahun 2007)

tangan asing. Sumber daya dieksploitasi dan bagian terbesar dari keuntungan mengalir ke luar negeri.

Pradeep Agrawal mengingatkan kemungkinan efek negatif dari berkembangnya perusahaan multinasional terhadap perkembangan perusahaan domestik. Kekhawatiran lainnya adalah kemungkinan terjadinya eksploitasi terhadap sumber daya ekonomi di negara-negara berkembang oleh perusahaan multinasional. ${ }^{25}$

Jenny Rebecca Kehl pun menggambarkan adanya paradoks ketergantungan suatu negara pada dana asing untuk membiayai pembangunan domestik. Terdapat perbedaan kepentingan yang jelas antara investor asing dan pemerintah dalam negeri. Kepentingan utama investor asing adalah untuk meningkatkan profitabilitas, daya saing, dan akses ke pasar internasional. Sebaliknya, kepentingan negara-negara berkembang adalah untuk mendorong pertumbuhan ekonomi domestik. ${ }^{26}$

Rencana Pembangunan Jangka Menengah Indonesia yang digariskan dalam Undang-Undang Nomor 17 Tahun 2007 tentang Rencana Pembangunan Jangka Panjang Tahun 2005-2025 (UU RPJP 2005-2025), jelas-jelas tidak menafikan adanya pengaruh asing terhadap pembangunan ekonomi Indonesia. Namun, dinamika globalisasi dan kesepakatan ekonomi dalam forum perjanjian internasional lah yang melahirkan berbagai kebijakan pemerintah yang menempatkan kepentingan nasional di atas segalanya. Kebijakan pembangunan ekonomi dalam jangka panjang tersebut harus mampu menjaga kemandirian kedaulatan ekonomi dan perhatian utama meningkatkan taraf hidup masyarakat serta menurunkan tingkat kemiskinan masyarakat yang masih lemah. ${ }^{27}$

\section{Prinsip Liberalisasi Perdagangan dalam WTO}

WTO merupakan suatu forum negara-negara dalam menyepakati pertukaran komitmen "liberalisasi" dengan cara mengurangi hambatan perdagangan dan menyetujui ketentuan-ketentuan yang harus ditaati negara anggota, seperti membuka akses pasar secara timbal balik. ${ }^{28}$ Pasal XVI ayat (4) Perjanjian Pembentukan WTO menjadi indikator penting WTO mewajibkan negara-negara anggotanya untuk menyesuaikan aturan-aturan atau hukum perdagangannya dengan aturan-aturan yang termuat dalam Annex WTO Agreement. ${ }^{29}$

25 Pradeep Agrawal, "Foreign Direct Investment in South Asia: Impact on Economic Growth and Local Investment", dalam buku Multinationals and Foreign Investment in Economic Development yang disusun oleh Edward M. Graham (eds), USA: Palgrave Macmillan, 2005, hlm. 94.

26 Jenny Rebecca Kehl, Foreign Investment and Domestic Development: Multinationals and the State, USA: Lynne Rienner Publishers Inc., 2009, hlm. 13.

27 Undang-Undang Nomor 17 Tahun 2007 tentang Rencana Pembangunan Jangka Panjang Tahun 2005-2025 : Bab IV.1. Arah Pembangunan Jangka Panjang Tahun 2005-2025, hlm. 48-49.

28 Bernard M. Hoekman dan Michael M. Kostecky, The Political Economy of the World Trading System: the WTO and Beyond, USA-New York: Oxford University Press, 2009, hlm. 28.

29 Huala Adolf, Hukum Perdagangan Internasional, Jakarta: Rajawali Pers, 2009, hlm. 39. 
Acep Rohendi: Prinsip Liberalisasi Perdagangan World Trade Organization (WTO) dalam Pembaharuan Hukum Investasi di Indonesia (Undang-Undang Nomor 25 Tahun 2007)

Liberalisasi ekonomi tampak dalam tiga pilar utama yakni: internasionalisasi dan liberalisasi perdagangan dan keuangan; dominasi perusahaan transnasional; dan peran luas dan mendalam dari 3 (tiga) organisasi ekonomi dunia yaitu International Monetary Fund (IMF), Bank Dunia, dan WTO. ${ }^{30}$

Institusi global yang berada di balik liberalisasi ekonomi, cikal bakalnya disepakati dalam Konferensi Bretton Woods yang diikuti oleh 44 negara yang dipimpin oleh Amerika Serikat dan Inggris pada tanggal 1-22 Juli 1944. ${ }^{31}$ Pada tahun 1947, Persetujuan Umum mengenai Tarif dan Perdagangan (GATT) diresmikan sebagai forum multilateral untuk mengurangi hambatan perdagangan..$^{32}$ WTO didirikan pada babak kedelapan perundingan GATT yang disebut sebagai Putaran Uruguay yang berlaku pada tanggal 1 Januari $1995 .^{33}$

$\mathrm{GATT}^{34}$ berpedoman pada 5 prinsip utama dalam perdagangan, yaitu: $:^{35}$

a. Prinsip Most-Favoured-Nation (MFN)

Prinsip ini terdapat dalam Pasal I GATT. Prinsip ini berarti suatu kebijakan perdagangan harus dilaksanakan atas dasar non-diskriminatif. Semua negara anggota terikat untuk memberikan perlakuan yang sama kepada negara-negara lainnya dalam pelaksanaan dan kebijakan impor dan ekspor serta yang menyangkut biaya-biaya lainnya.

b. Prinsip National Treatment

Prinsip ini terdapat dalam Pasal III GATT. Dalam prinsip ini, produk dari suatu negara yang diimpor ke dalam suatu negara harus diperlakukan sama seperti halnya produk dalam negeri. Prinsip ini sifatnya berlaku luas. Prinsip ini juga berlaku terhadap semua macam pajak dan pungutan-pungutan lainnya. Prinsip ini berlaku pula terhadap perundang-undangan, pengaturan, dan persyaratanpersyaratan (hukum) yang memengaruhi penjualan, pembelian, pengangkutan, distribusi, atau penggunaan produk-produk di pasar dalam negeri. Prinsip ini juga memberikan perlindungan terhadap proteksionisme sebagai akibat upaya-upaya atau kebijakan administratif atau legislatif.

c. Prinsip Larangan Restriksi (Pembatasan) Kuantitatif

Ketentuan dasar GATT adalah larangan restriksi kuantitatif merupakan rintangan terbesar bagi GATT. Restriksi kuantitatif terhadap ekspor atau impor dalam bentuk apapun (misalnya penetapan kuota impor atau ekspor, restriksi penggunaan lisensi impor atau ekspor, pengawasan pembayaran produk-produk

30 Ibid.

31 Richard Peet, Unholy Trinity: the IMF, World Bank and WTO, New York: Zedbook, 2009, hlm. 36.

32 Paul R. Krugman dan Maurice Obstfeld, Economics, USA: Worth Publishers, 2013, hlm. 546.

33 Masaaki Kotabe, Kristian Helsen, Global Marketing Management, USA: John Wiley \& Sons Inc., 2008, hlm. 56.

34 Ibid, hlm. 108-117.

35 lbid. 
Acep Rohendi: Prinsip Liberalisasi Perdagangan World Trade Organization (WTO) dalam Pembaharuan Hukum Investasi di Indonesia (Undang-Undang Nomor 25 Tahun 2007)

impor atau ekspor) pada umumnya dilarang (Pasal IX). Hal itu disebabkan praktik tersebut dapat mengganggu praktik perdagangan normal.

d. Prinsip Perlindungan melalui Tarif

Pada prinsipnya GATT hanya memperkenankan tindakan proteksi terhadap industri domestik melalui tarif (menaikkan tingkat tarif bea masuk) dan tidak melalui upaya-upaya perdagangan lainnya (non-tariff commercial measures). Perlindungan melalui tarif ini menunjukkan dengan jelas tingkat perlindungan yang diberikan dan masih memungkinkan adanya kompetisi yang sehat.

e. Prinsip Resiprositas

Prinsip ini merupakan prinsip fundamental dalam GATT. Prinsip ini tampak pada preambule GATT dan berlaku dalam perundingan-perundingan tarif yang didasarkan atas dasar timbal balik dan saling menguntungkan kedua belah pihak.

f. Perlakuan Khusus bagi Negara Berkembang

Sekitar dua pertiga negara anggota GATT adalah negara-negara yang sedang berkembang yang masih berada dalam tahap awal pembangunan ekonomi. Untuk membantu pembangunan mereka, pada tahun 1965, suatu bagian baru yaitu part IV yang memuat tiga pasal (Pasal XXXVI-XXXVIII), ditambahkan ke dalam GATT. Tiga pasal baru dalam bagian tersebut dimaksudkan untuk mendorong negara-negara industri membantu pertumbuhan ekonomi negaranegara berkembang.

\section{Prinsip-Prinsip Liberalisasi Investasi WTO dalam Pembaharuan UUPM Indonesia}

Terhitung 13 tahun sejak Indonesia menandatangani Perjanjian WTO Agreement (1994-2007), baru pada tahun 2007 lahir pembaharuan undang-undang penanaman modal. Krisis ekonomi 1997 merupakan salah satu trigger point pembaharuan hukum penanaman modal di Indonesia, yaitu pada saat Pemerintah Indonesia meminta bantuan IMF untuk menanggulangi krisis ekonomi melalui Surat Kesanggupan (Letter of Intent/Lol) Pemerintah Indonesia tanggal 31 Juli 2000 yang ditujukan kepada IMF. Lol tersebut berisi kesanggupan Pemerintah Indonesia untuk melaksanakan kebijakan-kebijakan ekonomi sebagai syarat permohonan bantuan keuangan dari IMF. Salah satu kesanggupan Pemerintah Indonesia tersebut adalah Lol tertanggal 31 Juni 2000 butir VII.62 yang berbunyi: "The government will shortly publish a regulation narrowing the list of sectors that are closed to foreign investment". Lol ini berisi kesanggupan Pemerintah Indonesia untuk membuat regulasi bagi investor asing untuk mendapatkan perluasan usaha dari sektor ekonomi bagi sektor-sektor ekonomi yang sebelumnya tertutup bagi investor asing. ${ }^{36}$

36 Indonesia-IMF, “Letter of Intent", 31 Juli 2000, <http://www.imf.org/external/np/loi/2000/idn/03/>, diunduh 10 Juni 2014. 
Acep Rohendi: Prinsip Liberalisasi Perdagangan World Trade Organization (WTO) dalam Pembaharuan Hukum Investasi di Indonesia (Undang-Undang Nomor 25 Tahun 2007)

Lol ini menunjukkan politik barter antara Pemerintah Indonesia dan IMF dalam paket bantuan ekonomi dari IMF. Salah satu bentuk politik barter dengan pembaharuan regulasi penanaman modal asing di Indonesia sesuai WTO Agreement, yang tiada lain adalah UUPMA sebagai produk hukum pembaharuan regulasi penanaman modal yang sebelumnya (UUPMA dan UUPMDN).

Prinsip-prinsip GATT (WTO) yang diimplementasikan dalam UUPM sebagai berikut:

a. Prinsip Most-Favoured-Nation (MFN)

Implementasi prinsip ini dalam UUPM dapat ditemukan dalam salah satu asas penanaman modal yaitu asas perlakuan yang sama dan tidak membedakan asal negara seperti diatur dalam Pasal 3 ayat (1) (d) UUPM. Maksud dari asas perlakuan yang sama dan tidak membedakan asal negara adalah asas perlakuan pelayanan non diskriminasi berdasarkan ketentuan peraturan perundangundangan, baik antara investor domestik dan investor asing maupun antara investor dari suatu negara asing dan investor dari negara asing lainnya. ${ }^{37}$

Pada Pasal 1 ayat (1) UUPM dinyatakan bahwa penanaman modal adalah segala bentuk kegiatan menanam modal, baik oleh investor domestik maupun asing untuk melakukan usaha di wilayah negara Republik Indonesia. Pasal ini merupakan awal pelaksanaan prinsip-prinsip MFN untuk memperlakukan secara sama terhadap investor domestik maupun asing. Hal ini diatur dalam Pasal 4 ayat (2) UU PMA ${ }^{38}$ yaitu dalam menetapkan kebijakan dasar penanaman modal, pemerintah memberi perlakuan yang sama bagi investor domestik dan asing dengan tetap memperhatikan kepentingan nasional.

Demikian pula dalam Pasal 6 ayat (1), dinyatakan bahwa Pemerintah Indonesia memberikan perlakuan yang sama kepada semua investor yang berasal dari negara manapun yang melakukan kegiatan penanaman modal di Indonesia sesuai dengan ketentuan peraturan perundang-undangan. Peraturan sebelum UUPM, pengaturan dan perlakuan terhadap investor asing dibedakan dengan adanya UUPMA 1967 dan UUPMDN 1968 beserta undang-undang perubahannya.

b. Prinsip National Treatment

Prinsip ini dapat ditemukan dalam Pasal 6 ayat (1) UUPM. Pada Pasal tersebut dinyatakan Pemerintah Indonesia memberikan perlakuan yang sama kepada

37 Penjelasan Pasal 3 ayat (1) (d) UUPM.

38 An-an Chandrawulan, Nia Kurniati, "Pelaksanaan Prinsip Non diskriminasi (Most Favoured Nations) dan Perlakuan Yang Sama (National Treatment) dalam Liberalisasi Penanaman Modal Asing dan Perlindungannya terhadap Pengusaha Kecil Domestik Khususnya Pengusaha Kecil dan Menengah di Indonesia", Laporan Penelitian Fakultas Hukum Universitas Padjadjaran, 2009, hlm. 20. 
Acep Rohendi: Prinsip Liberalisasi Perdagangan World Trade Organization (WTO) dalam Pembaharuan Hukum Investasi di Indonesia (Undang-Undang Nomor 25 Tahun 2007)

semua investor yang berasal dari negara manapun yang melakukan kegiatan penanaman modal di Indonesia sesuai dengan ketentuan peraturan perundangundangan. Perlakuan yang dimaksud tidak berlaku bagi penanam modal dari suatu negara yang memperoleh hak istimewa berdasarkan perjanjian dengan Indonesia.

Yang dimaksud dengan hak istimewa adalah hak istimewa yang berkaitan dengan kesatuan kepabeanan, wilayah perdagangan bebas, pasar bersama (common market), kesatuan moneter, kelembagaan yang sejenis, dan perjanjian antara Pemerintah Indonesia dan pemerintah asing yang bersifat bilateral, regional, atau multilateral yang berkaitan dengan hak istimewa tertentu dalam penyelenggaraan penanaman modal. ${ }^{39}$

c. Prinsip Larangan Restriksi (Pembatasan) Kuantitatif

Prinsip ini dapat ditemukan dalam Pasal 8 UUPM. Pada Pasal ini diatur bahwa penanam modal dapat mengalihkan aset yang dimilikinya kepada pihak yang diinginkan oleh penanam modal sesuai dengan ketentuan peraturan perundangundangan..$^{40}$ Aset yang tidak termasuk dalam pengertian aset sebagaimana dimaksud merupakan aset yang ditetapkan oleh undang-undang sebagai aset yang dikuasai oleh negara. ${ }^{41}$ Penanam modal diberi hak untuk melakukan transfer dan repatriasi dalam valuta asing, antara lain: modal keuntungan, bunga bank, deviden, dan pendapatan lain; dana yang diperlukan untuk pembelian bahan baku dan penolong, barang setengah jadi, atau barang jadi; atau penggantian barang modal dalam rangka melindungi kelangsungan hidup penanaman modal; tambahan dana yang diperlukan bagi pembiayaan penanaman modal; dana untuk pembayaran kembali pinjaman; royalti atau biaya yang harus dibayar; pendapatan dari perseorangan warga negara asing yang bekerja dalam perusahaan penanaman modal; hasil penjualan atau likuidasi penanaman modal; kompensasi atas kerugian; kompensasi atas pengambilalihan; pembayaran yang dilakukan dalam rangka bantuan teknis, biaya yang harus dibayar untuk jasa teknik dan manajemen, pembayaran yang dilakukan di bawah kontrak proyek, dan pembayaran hak atas kekayaan intelektual; dan hak untuk melakukan transfer dan repatriasi yang dilakukan sesuai dengan ketentuan peraturan. ${ }^{42}$

d. Prinsip Perlindungan melalui Tarif

Pelaksanaan prinsip ini ditemukan secara tersirat pada asas efisiensi berkeadilan

\footnotetext{
39 Penjelasan Pasal 6 ayat(2) UUPM.

40 Pasal 8 ayat 1 UUPM.

41 Pasal 8 ayat 2 UUPM.

42 Pasal 8 ayat 3 UUPM.
} 
Acep Rohendi: Prinsip Liberalisasi Perdagangan World Trade Organization (WTO) dalam Pembaharuan Hukum Investasi di Indonesia (Undang-Undang Nomor 25 Tahun 2007)

dalam UUPM. ${ }^{43}$ Yang dimaksud dengan asas efisiensi berkeadilan adalah asas yang mendasari pelaksanaan penanaman modal dengan mengedepankan efisiensi berkeadilan dalam usaha untuk mewujudkan iklim usaha yang adil, kondusif, dan berdaya saing. ${ }^{44}$

Demikian pula dalam Pasal 14 UUPM dinyatakan bahwa setiap investor berhak mendapat kepastian hak, hukum, dan perlindungan. Yang dimaksud dengan kepastian hak adalah jaminan Pemerintah Indonesia bagi investor untuk memperoleh hak sepanjang mereka telah melaksanakan kewajiban yang ditentukan. Yang dimaksud dengan kepastian hukum adalah jaminan Pemerintah Indonesia untuk menempatkan hukum dan ketentuan peraturan perundangundangan sebagai landasan utama dalam setiap tindakan dan kebijakan bagi investor. Yang dimaksud dengan kepastian perlindungan adalah jaminan pemerintah bagi penanam modal untuk memperoleh perlindungan dalam melaksanakan kegiatan penanaman modal. ${ }^{45}$

e. Prinsip Resiprositas

Prinsip ini dapat ditemukan dalam Pasal 7 UUPM. Pada Pasal ini dinyatakan bahwa pemerintah tidak akan melakukan tindakan nasionalisasi atau pengambilalihan hak kepemilikan penanam modal, kecuali dengan undangundang. Jika pemerintah melakukan tindakan nasionalisasi atau pengambilalihan hak kepemilikan, Pemerintah Indonesia akan memberikan kompensasi yang jumlahnya ditetapkan berdasarkan harga pasar.

Pada Pasal 32 UUPM diatur jika terjadi sengketa di bidang penanaman modal antara pemerintah dan penanam modal, maka para pihak terlebih dahulu menyelesaikan sengketa tersebut melalui musyawarah mufakat. Jika dalam hal penyelesaian sengketa tersebut tidak tercapai kesepakatan, maka penyelesaian sengketa tersebut dapat dilakukan melalui arbitrase, alternatif penyelesaian sengketa atau pengadilan sesuai dengan ketentuan peraturan perundangundangan. Jika terjadi sengketa di bidang penanaman modal antara Pemerintah Indonesia dan penanam modal asing, maka para pihak akan menyelesaikan sengketa tersebut melalui arbitrase internasional yang harus disepakati oleh para pihak. ${ }^{46}$

f. Perlakuan Khusus bagi Negara Berkembang

Perlakuan ini diatur dalam Pasal 13 UUPM. Pada Pasal ini dinyatakan bahwa Pemerintah Indonesia wajib menetapkan bidang usaha yang dicadangkan untuk

43 Pasal 3 ayat (1) butirf UUPM.

44 Penjelasan Pasal 3 ayat (1) butir fUUPM.

45 Penjelasan Pasal 14 UUPM.

46 Pasal 32 ayat (4) UUPM. 
Acep Rohendi: Prinsip Liberalisasi Perdagangan World Trade Organization (WTO) dalam Pembaharuan Hukum Investasi di Indonesia (Undang-Undang Nomor 25 Tahun 2007)

usaha mikro, kecil, menengah, dan koperasi serta bidang usaha yang terbuka untuk usaha besar dengan syarat harus bekerja sama dengan usaha mikro, kecil, menengah, dan koperasi. Dari ketentuan ini berarti dalam penanaman modal, para pemodal dibatasi dalam bidang-bidang usaha tertentu untuk bekerja sama dengan usaha mikro, kecil, menengah, dan koperasi. Di samping itu, bidangbidang usaha yang diperuntukkan untuk usaha mikro, kecil, menengah, dan koperasi.

Penerapan prinsip-prinsip GATT/WTO dalam suatu negara akibat proses globalisasi ekonomi bukan suatu fenomena yang netral. Tidak hanya menghilangkan sekat-sekat batas negara karena kemajuan komunikasi dan teknologi informasi, globalisasi juga menyebarkan ide-ide atau muatan-muatan kapitalisme dan pasar bebas ke semua negara. ${ }^{47}$ Sesungguhnya globalisasi adalah kelanjutan dari kolonialisme dan developmentalism. ${ }^{48}$ negara-negara Eropa ke wilayah negaranegara Asia-Afrika beberapa abad yang lalu. Perbedaannya, kolonisasi menduduki wilayah suatu negara dengan kekuatan senjata (militer). Globalisasi merupakan serbuan produk barang/jasa atau tenaga kerja asing ke suatu wilayah negara. ${ }^{49}$

Adanya dua pandangan dari para ekonom tersebut tentang keberadaan FDI dalam suatu negara telah dipertimbangkan oleh para pengambil kebijakan negara Indonesia ketika membuat undang-undang penanaman modal asing pertama kali pada tahun 1967 dalam rangka pembangunan ekonomi Indonesia. Dasar pembangunan ekonomi Indonesia saat itu terkandung dalam Pasal 10 Ketetapan MPRS Nomor XXIII/MPRS/1966 tentang Pembaharuan Kebijakan Landasan Ekonomi Keuangan dan Pembangunan (TAP MPRS 1966).

TAP MPRS 1966 menunjukan arah kepada para pengambil kebijakan negara Indonesia bahwa investasi asing atau bantuan luar negeri tidak dinafikan kontribusinya dalam membangun ekonomi Indonesia yang sedang merosot, tetapi harus terlebih dahulu mengandalkan kemampuan potensi domestik sebagai sumber dana pembangunan. Keberadaan sumber-sumber dana dari luar negeri tidak mengakibatkan ketergantungan kepada pihak luar negeri dan sumber dana asing tersebut harus digunakan untuk kepentingan ekonomi rakyat. Nampaknya jiwa TAP MPRS 1966 ini mengisyaratkan kemandirian bangsa Indonesia untuk melakukan pembangunan ekonomi serta kedaulatan negara Indonesia sebagai sebuah negara yang harus dijaga dalam kaitannya dengan aliran dana dari luar negeri ke negara

47 R. Hendra Halwani, Ekonomi Internasional \& Globalisasi Ekonomi, Jakarta: Ghalia Indonesia, 2002, hlm. 225-226.

48 Mansour Fakih, "Neoliberalisme Dan Globalisasi", Ekonomi Politik Digital Journal Al-Manär, Edisi l/2004, hlm. 6.

49 A.F. Elly Erawaty, "Globalisasi Ekonomi dan Perdagangan Bebas" dalam buku Aspek Hukum dari Perdagangan Bebas: Menelaah Kesiapan Hukum Indonesia Melaksanakan Perdagangan Bebas yang disusun oleh Ida Susanti dan Bayu Seto (eds.), Bandung: PT. Citra Aditya Bakti, 2003, hlm. 8. 
Acep Rohendi: Prinsip Liberalisasi Perdagangan World Trade Organization (WTO) dalam Pembaharuan Hukum Investasi di Indonesia (Undang-Undang Nomor 25 Tahun 2007)

Indonesia. Hal tersebut juga tidak serta merta mengorbankan kedaulatan negara demi pembangunan ekonomi atau kepentingan ekonomi rakyat dalam pembangunan negara melalui pembangunan ekonomi. Seperti yang dinyatakan oleh Sunaryati Hartono, TAP MPRS 1966 ini harus menjadi patokan pemerintah pada saat itu dalam menentukan kebijakan ekonominya, khususnya di bidang penanaman modal asing. ${ }^{50}$

TAP MPRS 1966 merupakan salah satu landasan hukum lahirnya regulasi penanaman modal di Indonesia yaitu UUPMA. Setahun kemudian lahir UUPMDN yang mengatur investasi dalam pembangunan ekonomi Indonesia yang sumber dananya berasal dari modal domestik. ${ }^{51}$ Keberadaan UUPMA dan UUPMDN merupakan kebijakan ekonomi Orde Baru dalam rangka memulihkan perekonomian Indonesia yang memburuk pada saat peralihan dari Orde Lama ke Orde Baru. Kendala dalam perkembangan ekonomi yang berkelanjutan di antaranya adalah keterbatasan investasi. $^{52}$

UUPMA dan UUPMDN beserta perubahannya perlu diganti karena 'dianggap' tidak sesuai lagi dengan kebutuhan percepatan perkembangan perekonomian dan pembangunan hukum nasional, khususnya di bidang penanaman modal. ${ }^{53}$ Pembaharuan UUPM tentang modal adalah tidak lagi membedakan modal asing dan modal dalam negeri. Hal ini mengandung konsekuensi untuk memperlakukan secara sama investor asing dan investor domestik. Pelaku ekonomi di Indonesia sebagai investor domestik, meliputi BUMN/BUMD, swasta, dan koperasi. Kelompok usaha swasta dapat meliputi usaha besar, usaha menengah, usaha kecil, dan usaha mikro. ${ }^{54}$

Pada intinya, liberalisasi penanaman modal ini memberi perlindungan penuh kepada pemilik investasi asing atau perusahaan multinasional serta mengurangi sampai sedikit mungkin hak pemerintah negara tuan rumah untuk mengendalikan arus modal asing. Di satu pihak liberalisasi atau globalisasi perdagangan internasional dan penanaman modal asing ini dapat menarik produk-produk Indonesia ke pasaran dunia apabila semakin banyak komponen dari produk-produk yang patennya dimiliki oleh perusahaan multinasional dapat dibuat di Indonesia. Di lain pihak, muncul pertanyaan dapatkah Indonesia berperan sebagai pelaku dalam perdagangan global yang pemain utamanya adalah perusahaan multinasional. Hal ini akan banyak menimbulkan masalah karena konflik kepentingan antara perusahaan multinasional

50 Sunaryati Hartono, Beberapa Masalah Transnasional dalam Penanaman Modal Asing di Indonesia, Bandung: Binacipta, 1972, hlm. 29.

51 Erman Rajagukguk, Loc.cit.

52 DidikJ. Rachbini, Arsitektur Hukum Investasi...., Op.cit., hlm. 21-22.

53 Konsiderans/Pertimbangan Butir e UUPM.

54 Lihat Pasal 1 angka (1) angka (4) Undang-Undang Nomor 20 Tahun 2008 tentang Usaha Mikro, Kecil, dan Menengah. 
Acep Rohendi: Prinsip Liberalisasi Perdagangan World Trade Organization (WTO) dalam Pembaharuan Hukum Investasi di Indonesia (Undang-Undang Nomor 25 Tahun 2007)

yang menanamkan modalnya di Indonesia dan pembangunan ekonomi nasional Indonesia itu sendiri. ${ }^{55}$

Di satu sisi, Indonesia harus membuat peraturan atau ketentuan-ketentuan yang memudahkan perusahaan-perusahaan multinasional untuk menanamkan modalnya di Indonesia. Di lain sisi ketentuan-ketentuan yang dikeluarkan pun tidak boleh bertentangan dengan landasan ekonomi Indonesia yang terdapat dalam Pasal 33 UUD 1945 dan Pancasila. ${ }^{56}$

Implementasi prinsip-prinsip liberalisasi Perjanjian WTO dalam peraturan perundang-undangan di bidang pembangunan ekonomi di Indonesia, seperti terkandung dalam UUPM, pada dasarnya tidak selaras dengan jiwa Pancasila dan UUD 1945. Di satu sisi, pembangunan ekonomi Indonesia pada dasarnya bertujuan mewujudkan keadilan sosial bagi seluruh rakyat Indonesia sebagai tujuan akhir pelaksanaan sila-sila Pancasila dan UUD 1945. Di sisi lain, Syamsul Hadi menilai UUPM mengandung sejumlah pasal yang justru mengesampingkan kepentingan rakyat Indonesia, seperti hak asing atas kepemilikan tanah yang berjangka panjang serta jaminan kebebasan untuk mengalihkan aset yang dimiliki kepada pihak-pihak yang diinginkan. ${ }^{57}$ Penilaian Syamsul Hadi terhadap pasal-pasal UUPM tersebut jelas-jelas bertentangan dengan tujuan Pancasila dan UUD 1945 untuk mewujudkan keadilan sosial bagi seluruh rakyat Indonesia.

Dua kepentingan lain, selain kepentingan ekonomi dan kepentingan hukum, yang juga kontradiktif adalah kepentingan perusahaan multinasional penanam modal dan kepentingan negara Indonesia yang sedang melaksanakan pembangunan ekonomi. Keberadaan investasi asing dalam negara berkembang pada dasarnya membawa manfaat (benefit) dan sekaligus mudarat (negative impact). Manfaat investasi asing dalam negara berkembang adalah menutup "savings-investment gap in the economy" serta membawa tambahan sumber daya seperti teknologi, management know-how, dan akses ke pasar barang ekspor. ${ }^{58}$ Sebaliknya investasi asing membawa pengaruh negatif di bidang politik, budaya, dan ekonomi, seperti: campur tangan dalam urusan dalam negeri, perubahan budaya, ketergantungan teknologi, modal domestik tersisih, dominasi dalam industri dan produk lokal tersisih, keringanan pajak, polusi lingkungan, dan kestabilan neraca pembayaran. ${ }^{59}$

An-An Chandrawulan, Hukum Perusahaan Multinasional, Liberalisasi Hukum Perdagangan Internasional dan Hukum Penanaman Modal, Bandung: Alumni, 2011, hlm. 15.

56 Ibid.

57 Syamsul Hadi (et.al), Kudeta Putih: Reformasi dan Pelembagaan Kepentingan Asing dalam Ekonomi Indonesia, Jakarta: Indonesia Berdikari, 2012, hlm. 2.

58 H.S. Kehal, Foreign Investment in Developing Countries, New York: Palgrave Macmillan, 2004, hlm. 1.

59 Ibid., hlm. 40. 
Acep Rohendi: Prinsip Liberalisasi Perdagangan World Trade Organization (WTO) dalam Pembaharuan Hukum Investasi di Indonesia (Undang-Undang Nomor 25 Tahun 2007)

Berkaitan dengan hal tersebut, sesuai dengan Pasal 2 Ketetapan MPR Nomor XVI/MPR/1998 tentang Politik Ekonomi dalam Rangka Demokrasi Ekonomi bahwa politik ekonomi nasional diarahkan untuk menciptakan struktur ekonomi nasional agar terwujud pengusaha menengah yang kuat dan besar jumlahnya serta terbentuknya keterkaitan dan kemitraan yang saling menguntungkan antar pelaku ekonomi yang meliputi usaha kecil, menengah, dan koperasi, usaha besar swasta, dan BUMN yang saling memperkuat untuk mewujudkan demokrasi ekonomi dan efesien nasional yang berdaya saing tinggi.

Arah investasi di Indonesia menurut UU RPJP 2005-2025 adalah untuk mendukung terwujudnya pertumbuhan ekonomi yang cukup tinggi secara berkelanjutan dan berkualitas dengan mewujudkan iklim investasi yang menarik; mendorong penanaman modal asing bagi peningkatan daya saing perekonomian nasional; serta meningkatkan kapasitas infrastruktur fisik dan pendukung yang memadai. Investasi yang dikembangkan dalam rangka penyelenggaraan demokrasi ekonomi akan dipergunakan sebesar-besarnya untuk pencapaian kemakmuran bagi rakyat. $^{60}$

\section{Penutup}

Indonesia sebagai negara anggota WTO telah melaksanakan Pasal XVI ayat (4) WTO Agreement, yang mewajibkan negara-negara anggotanya untuk menyesuaikan aturan-aturan atau hukum perdagangannya dengan lahirnya UUPM. Prinsip-prinsip WTO oleh negara Indonesia telah diimplementasikan dalam UUPM sebagai berikut:

1. Prinsip Most-Favoured-Nation dalam Pasal 1 ayat (1) dan Pasal 3 ayat (1) UUPM Pasal 4 ayat (2) dan Pasal 6 ayat (1) UUPM.

2. Prinsip National Treatment dalam Pasal 6 ayat (1) UUPM.

3. Prinsip Larangan Restriksi (Pembatasan) Kuantitatif dapat ditemukan dalam Pasal 8 UUPM.

4. Prinsip Perlindungan Melalui Tarif ditemukan secara tersirat pada asas efisiensi berkeadilan dalam Pasal 3 ayat (1) dan Pasal 14 UUPM.

5. Prinsip Resiprositas dapat ditemukan dalam Pasal 7 dan Pasal 32 UUPM .

6. Perlakuan khusus bagi negara berkembang diatur dalam Pasal 13 UUPM .

Berdasarkan kesimpulan di atas, pemerintah perlu menciptakan perusahaan nasional yang kuat dan mampu bersaing dengan perusahaan multinasional yang menanamkan modalnya di Indonesia. Kebijakan mutlak diperlukan agar perusahaan asing berorientasi ekspor dan kehadiran investor asing tidak mengganggu neraca

60 Undang-Undang Nomor 17 Tahun 2007 tentang Rencana Pembangunan Jangka Panjang Tahun 2005-2025: Bab IV.1. Arah Pembangunan Jangka Panjang Tahun 2005-2025, hlm. 50. 
Acep Rohendi: Prinsip Liberalisasi Perdagangan World Trade Organization (WTO) dalam Pembaharuan Hukum Investasi di Indonesia (Undang-Undang Nomor 25 Tahun 2007)

pembayaran Indonesia. Pemerintah pun berkewajiban untuk meningkatkan peran Usaha Mikro, Kecil, dan Menengah (UMKM) agar tidak terpinggirkan oleh investor yang besar dan kuat. Pembaharuan undang-undang penanaman modal dalam jangka panjang perlu mengkritisi dan memperhatikan pengaruh WTO Agreement dalam undang-undang investasi di Indonesia.

\section{Daftar Pustaka}

\section{Buku}

An-An Chandrawulan, Hukum Perusahaan Multinasional, Liberalisasi Hukum Perdagangan Internasional dan Hukum Penanaman Modal, Alumni, Bandung, 2011.

Graham, Edward M. (eds), Multinationals and Foreign Investment in Economic Development, Palgrave Macmillan, USA, 2005.

Didik J. Rachbini, Arsitektur Hukum Investasi Indonesia (Analisis Ekonomi Politik), PT Indeks, Jakarta, 2008.

Gadner, Bryan A., Black's Law Dictionary, Thomson, USA, 2004.

Hoekman, Bernard M, Michael M. Kostecky, The Political Economy of The World Trading System: The WTO and Beyond, Oxford University Press, New York, 2009.

Huala Adolf, Hukum Perdagangan Internasional, Rajawali Pers, Jakarta, 2009.

Ida Susanti dan Bayu Seto (eds), Aspek Hukum dari Perdagangan Bebas: Menelaah Kesiapan Hukum Indonesia Melaksanakan Perdagangan Bebas, PT. Citra Aditya Bakti, Bandung, 2003.

Jonker Sihombing, Hukum Penanaman Modal Indonesia, Alumni, Bandung, 2009.

Kehal, H.S., Foreign Investment in Developing Countries, Palgrave Macmillan, New York, 2004.

Kehl Jenny Rebecca, Foreign Investment and Domestic Development: Multinationals and the State, Lynne Rienner Publishers Inc., USA, 2009.

Krugman, Paul R. and Maurice Obstfeld, Economics, Worth Publishers, USA, 2013.

Masaaki, Kotabe dan Kristian Helsen, Global Marketing Management, John Wiley \& Sons Inc., USA, 2008.

Mochtar Kusumaatmadja dan B.Arief Sidharta, Pengantar Ilmu Hukum: Suatu Pengenalan Pertama Ruang Lingkup Berlakunya Ilmu Hukum, Alumni, Bandung, 2000.

Panic, Milivoje, Globalization and National Economic Welfare, Palgrave Macmillan, New York, 2003.

Peet, Richard, Unholy Trinity: the IMF, World Bank and WTO, Zedbook, New York, 2009. 
Acep Rohendi: Prinsip Liberalisasi Perdagangan World Trade Organization (WTO) dalam Pembaharuan Hukum Investasi di Indonesia (Undang-Undang Nomor 25 Tahun 2007)

Petrus C.K.L Bello, Ideologi Hukum: Refleksi Filsafat atas Ideologi di Balik Hukum, Insan Merdeka, Bogor, 2013.

R. Hendra Halwani, Ekonomi Internasional \& Globalisasi Ekonomi, Ghalia Indonesia, Jakarta, 2002.

Rutherford, Donald, Routledge Dictionary of Economics, Routledge, New York, 2005.

The World Bank Group, Investing Across Borders 2010: Indicators of Foreign Direct Investment Regulation in 87 Economies, Washington D.C: The World Bank Group, 2010.

Sentosa Sembiring, Hukum Investasi, Nuansa Aulia, Bandung, 2010.

Sornarajah, M., The International Law on Foreign Investment, Cambridge University Press, New York, 2010.

Stearns, Peter N., Globalization in World History, Routledge, USA, 2010.

Sudikno Mertokusumo, Mengenal Hukum, Liberty, Yogyakarta, 1995.

Sujud Margono, Hukum Investasi Asing, CV. Novindo Pustaka Mandiri, Jakarta, 2008.

Sunaryati Hartono, Beberapa Masalah Transnasional dalam Penanaman Modal Asing di Indonesia, Binacipta, Bandung, 1972.

, Politik Hukum Menuju Satu Sistem Hukum Nasional, Alumni, Bandung, 1991.

Syamsul Hadi (et.al), Kudeta Putih: Reformasi dan Pelembagaan Kepentingan Asing dalam Ekonomi Indonesia, Indonesia Berdikari, Jakarta, 2012.

Zarsky, Lyuba (eds.), International Investment for Sustainable Development: Balancing Rights and Rewards, Earthscan, London, 2005.

\section{Dokumen Lain}

An-An Chandrawulan dan Nia Kurniati, "Pelaksanaan Prinsip Non Diskriminasi (Most Favour Nations) dan Perlakuan Yang Sama / (National Treatment) Dalam Liberalisasi Penanaman Modal Asing dan Perlindungannya Terhadap Pengusaha Kecil Domestik Khususnya Pengusaha Kecil dan Menengah di Indonesia", Laporan Penelitian Fakultas Hukum Universitas Padjadjaran, 2009.

Erman Rajagukguk, "The New Indonesian Investment Law", Paper presented at Current Issues in Indonesian Law, in Honor of Professor Emeritus Daniel S.Lev, $\mathrm{S}$ e a t I e, $\quad 27-28 \quad \mathrm{Fe} \mathrm{bruary} 2007$, http://www.ermanhukum.com/Makalah\%20ER\%20pdf/THE\%20NEW\%20INDO NESIAN\%20INVESTMENT\%20LAW.pdf, diunduh 1 Juni 2014.

Indonesia-IMF, "Letter of Intent", 31 Juli 2000,

http://www.imf.org/external/np/loi/2000/idn/03/, diunduh 10 Juni 2014.

Larose. Peter, "The Impact of Global Financial Integration on Mauritius and Seychelles", Bank of Valletta Review, Nomor 28, 2003. 
Acep Rohendi: Prinsip Liberalisasi Perdagangan World Trade Organization (WTO) dalam Pembaharuan Hukum Investasi di Indonesia (Undang-Undang Nomor 25 Tahun 2007)

Mansour Fakih, "Neoliberalisme Dan Globalisasi", Ekonomi Politik Digital Journal Al-Manär, Edisi I/2004.

Ruggiero, Renato, "WTO News: 1996 Press Releases", http://www.wto.org/english/news_e/pres96_e/pr042_e.htm, diunduh 20 Mei 2014.

\section{Dokumen Hukum}

Agreement Estabilishing the World Trade Organization, 1994.

Undang-Undang Nomor 1 Tahun 1967 tentang Penanaman Modal Asing.

Undang-Undang Nomor 5 Tahun 1968 tentang Penanaman Modal dalam Negeri.

Undang-Undang Nomor 7 Tahun 1994 tentang Pengesahan Agreement Establishing

The World Trade Organization (Persetujuan Pembentukan Organisasi Perdagangan Dunia).

Undang-Undang Nomor 17 Tahun 2007 tentang Rencana Pembangunan Jangka Panjang Tahun 2005-2025.

Undang-Undang Nomor 25 Tahun 2007 tentang Penanaman Modal.

Undang-Undang Nomor 20 Tahun 2008 tentang Usaha Mikro, Kecil, dan Menengah.

Undang-Undang Nomor 12 Tahun 2011 tentang Pembentukan PerundangUndangan. 